\title{
Cloning, purification and enzymatic characterization of recombinant human superoxide dismutase 1 (hSOD1) expressed in Escherichia coli
}

\author{
Feng Lin'1,2,3, Dandan Yan², Yawen Chen², Fletcher Emmanuella E², Haifeng Shi², \\ Bangxing Han ${ }^{4}$ and Yang Zhou ${ }^{2}$
}

\begin{abstract}
1School of Food and Biological Engineering, Jiangsu University, Zhenjiang 212013, P. R. China; ${ }^{2}$ Institute of Life Sciences, Jiangsu University, Zhenjiang 212013, P. R. China; ${ }^{3}$ Key Laboratory of Healthy Freshwater Aquaculture, Ministry of Agriculture, Zhejiang Institute of Freshwater Fisheries, Huzhou 313001, P. R. China; ${ }^{4}$ College of Biological and Pharmaceutical Engineering, West Anhui University, Moon Island, Lu'an 237012, P. R. China
\end{abstract}

Superoxide dismutase 1 (SOD1) is a metalloenzyme that catalyzes the disproportionation of superoxide into molecular oxygen and hydrogen peroxide. In this study, the human SOD1 (hSOD1) gene was cloned, expressed and purified. The hSOD1 gene was amplified from a pool of Bxpc3 cell cDNAs by PCR and cloned into expression vector pET-28a (+). The recombinant soluble hSOD1 was expressed in E. coli BL21 (DE3) at $37{ }^{\circ} \mathrm{C}$ and purified using nickel column affinity chromatography. Soluble hSOD1 was produced with a yield of $5.9 \mu \mathrm{g} / \mathrm{mL}$ medium. As metal ions can have a certain influence on protein structure and activity, we researched the influences of different concentrations of $\mathrm{Cu}^{2+}$ and $\mathrm{Zn}^{2+}$ on hSOD1 activity at induction and the time of activity detection. The results implied that $\mathrm{Cu}^{2+}$ and $\mathrm{Zn}^{2+}$ do not enhance SOD1 expression and solubility; they can, however, improve the catalytic activity at induction. Meanwhile, $\mathrm{Cu}^{2+}$ and $\mathrm{Zn}^{2+}$ also enhanced the enzyme activity at the time of detection. Furthermore, most other bivalent cations had the potential to replace $\mathrm{Zn}^{2+}$ and $\mathrm{Cu}^{2+}$, and also improved enzyme activity at the time of detection.

Key words: superoxide dismutase 1, Escherichia coli, soluble expression, metal ions, catalytic activity

Received: 08 November, 2017; revised: 15 February, 2018; accepted: 17 February, 2018; available on-line: 30 May, 2018

\e-mail: zhouyang@ujs.edu.cn

Abbreviations: hSOD1, human superoxide dismutase 1; GSH-Px, glutathione peroxidase; IPTG, isopropyl- $\beta$-D-thiogalactoside

\section{INTRODUCTION}

The antioxidant defense system is extremely important as it enables living organisms to scavenge free radicals produced during normal metabolism. Several antioxidative enzymes are known to reduce oxidative damage, such as superoxide dismutase (SOD), glutathione reductase, catalase (CAT) and glutathione peroxidase (GSHPx) (Shih et al., 2006; Geraghty et al., 2016). Although all of them exhibit definite antioxidative action, SOD is considered the first enzyme in the defense against oxidative stress produced during normal metabolism (Johnson, 2002).

SODs are a major antioxidant enzyme family whose members can convert superoxide radicals to hydrogen peroxide which is further catalyzed to form $\mathrm{H}_{2} \mathrm{O}$ and $\mathrm{O}_{2}$ (Kilic et al., 2014; Vats et al., 2015). Three forms of SOD are present in humans, in all other mammals, and most chordates. SOD1 is expressed in the intermembrane space of mitochondria, the nucleus, and the cyto- sol. SOD2 is located in the mitochondrial matrix, while SOD3 is secreted into the extracellular space (Hole et al., 2011). SOD1 is a homodimer consisting of two $16-\mathrm{kDa}$ subunits found in the cytoplasm and nucleus of the cell. SOD2 is mitochondrial and the human enzyme has manganese $(\mathrm{Mn})$ in its reactive center and active site, which functions as a metal cofactor (Ghneim, 2016).

Heterologous expression of SOD1 has been conducted in many expression systems including E. coli (Hartman et al., 1986; Zhang et al., 2017), yeast (Yoo et al., 1999; Wu et al., 2009), baculovirus systems (Fujii et al., 1995; Hayward et al., 2002) and plant cells (Park et al., 2002). The recombinant hSOD1 proteins are in all cases expressed in the cytosol, and in E. coli yields are equivalent to at least $10 \%$ of the total bacterial protein, and in many cases much more (Ahl et al., 2004). However, the most common problem has been that the protein produced is $\mathrm{Cu}^{2+}$ and $\mathrm{Zn}^{2+}$-deficient at active site resulting in low solubility and enzyme activity. Metal reconstitution in vitro is a method of incorporating $\mathrm{Cu}^{2+}$ into the apoenzyme (apo-hSOD1). The addition of $\mathrm{Cu}^{2+}$ into the $E$. coli culture was reported to improve $\mathrm{Cu}^{2+}$ incorporation; however, the production of SOD1 with a full $\mathrm{Cu}^{2+}$ complement was still a complication.

SOD1 is a metalloenzyme containing one copper ions and one zinc ion per molecule. Many early investigations of SOD1 focused on the metal-binding properties of the enzyme. The structural integrity of SOD1 depends critically on the correct coordination of zinc and copper (Nordlund et al., 2009). Banci et al. found by in-cell NMR that hSOD1 needs to bind one $\mathrm{Zn}^{2+}$ ion and one catalytic $\mathrm{Cu}^{2+}$ ion per molecule and to form an intramolecular disulfide bridge before it exerts its catalytic function (Banci et al., 2011). Defective metal binding or decreased affinity for zinc and copper is a feature of many SOD1 mutants and has been suggested to play a role in the pathogenic mechanism of amyotrophic lateral sclerosis (ALS) (Sangwan et al., 2017). However, excess cofactors can create toxicity, i.e. zinc toxicity may be due to the binding of zinc to inappropriate sites that inhibit enzyme function or to the displacement of other metal ions from the active sites of enzymes (Wu et al., 2009).

In this research, the open reading frame (ORF) of hSOD1 was cloned and the recombinant enzyme was expressed in E. coli BL21 (DE3). The antioxidative activity of the recombinant hSOD1 protein was detected. Because the zinc and copper cofactors are involved in the stable structure and high activity of eukaryotic SOD1 (Leitch et al., 2009; Girotto et al., 2014; Lin et al., 2015), we investigated the influences of $\mathrm{Cu}^{2+}$ and $\mathrm{Zn}^{2+}$ on 
hSOD1 activity at induction. Meanwhile, we also studied the effects of $\mathrm{Cu}^{2+}$ and $\mathrm{Zn}^{2+}$ on hSOD1 enzymatic activity. Furthermore, we examined the effects of substitutions of metal ions on hSOD1 activity at the time of detection.

\section{MATERIALS AND METHODS}

Materials. TRIzol (Sangon Biotech, China), random hexamers (50 ng/mL), dNTP Mix (10 mM each), 0.1 M DT'T, $5 \times$ first strand buffer, reverse transcriptase MMLV (Rnase H-), rTaq polymerase, restriction enzymes, T4 DNA ligase, DNA markers and protein markers were purchased from TaKaRa (Dalian, China). The expression vector pET-28a $(+)$ and E. coli strain DH5 $\alpha$, BL21 were obtained in our lab. All chemicals were all from Sigma (St. Louis, MO, USA) or a domestic provider in China if not stated otherwise.

Construction of an expression vector containing the hSOD1 gene. The hSOD1 specific primers, forward primer (5' CCAAGCTTGGATGGCGACGAAGGCCGTG 3') with a HindIII site (underlined), and reverse primer (5' CCCTCGAGGGTTATTGGGCGATCCCAAT 3') with an XhoI site (underlined) were designed to amplify the hSOD1 gene (GenBank accession number CR541742.1). cDNA of Bxpc3 cell lines served as a template for amplifying the hSOD1 gene with PCR. Following this, the PCR product was digested using two kinds of restriction endonucleases (HindIII and XhoI). Finally, the digested product was cloned into expression vector pET-28a (+) between the HindIII and XhoI restriction sites. The recombinant plasmid was verified by DNA sequencing.

Expression and purification of the recombinant protein. The constructed recombinant expression plasmids were transformed into E. coli BL21 (DE3) for protein production. The freshly transformed colony was cultured in LB medium supplemented with kanamycin $(50 \mu \mathrm{g} / \mathrm{mL})$. Expression of the recombinant protein was induced by $1 \mathrm{mM}$ isopropyl- $\beta$-D-1-thiogalactopyranoside (IPTG) for $6 \mathrm{~h}$ at $37^{\circ} \mathrm{C}$. Cells were harvested by centrifugation $\left(4500 \times \mathrm{g}, 4^{\circ} \mathrm{C}, 15 \mathrm{~min}\right)$. The cell pellet was resuspended in Tris- $\mathrm{HCl}(50 \mathrm{mM}, \mathrm{pH} 8.0)$, and then incubated with $1 \mathrm{mg} / \mathrm{mL}$ lysozyme on ice for $30 \mathrm{~min}$. Finally, the suspension was lysed by sonication, and the precipitate and supernatant were separated by centrifugation twice at $8000 \times g$ and $4^{\circ} \mathrm{C}$ for $20 \mathrm{~min}$.

The supernatant was loaded onto a Ni-NTA affinity column (GenScript, Nanjing, China). Purification conditions followed the manufacturer's instructions. After washing the column with $50 \mathrm{mM}$ and $100 \mathrm{mM}$ imidazole, the fusion protein was eluted with $400 \mathrm{mM}$ imidazole. The eluted protein was dialyzed against dialysis buffer $(50 \mathrm{mM}$ Tris- $\mathrm{HCl}, \mathrm{pH} 8.0)$ at $4^{\circ} \mathrm{C}$ to remove imidazole. The protein concentration was detected by the BCA Protein Assay Kit (Pierce, Bonn, Germany).

Western blotting. Western blotting was performed according to the method described by Zhou and coworkers (Zhou et al., 2017). Proteins were resolved on a $15 \%$ SDS-PAGE gel and electro-transferred onto a PVDF membrane. The membrane was subsequently blocked and incubated with mouse anti His-tag antibody (1:1000 dilution) at $4^{\circ} \mathrm{C}$ overnight, followed by goat anti-mouse IgG (1:2000 dilution) for $2 \mathrm{~h}$. Lastly, the bands were visualized with ECL Western Blotting Substrate (Vazyme, Nanjing, China).

Enzymatic activity assay. The catalyzing activity of the recombinant hSOD1 was measured using CuZn-
SOD and Mn-SOD Assay Kits with WST-8 (Beyotime Biotechnology, Shanghai, China). The assay was based on measuring the color of a formazan dye. According to the manufacturers' instructions, the WST-8/enzyme working solution and reaction starting solution were prepared beforehand. A preliminary experiment was conducted to find the optimal amount of hSOD1, so that the inhibition percentage of hSOD1 lay between $30 \%$ and $70 \%$. A certain amount of hSOD1 (final volume was $20 \mu \mathrm{L}$ ), WST-8/enzyme working solution $(160 \mu \mathrm{L})$ and reaction starting solution $(20 \mu \mathrm{L})$ were incubated at $37{ }^{\circ} \mathrm{C}$ for 30 min. The absorbance at $450 \mathrm{~nm}$ was detected. Crude cell lysate (only containing pET-28a (+)) was regarded as a negative control. The activity of hSOD1 was calculated according to the formula in the manufacturers' instructions.

The influence of $\mathrm{Cu}^{2+}$ and $\mathrm{Zn}^{2+}$ on hSOD1 activity at induction. Overnight cultured bacteria were inoculated into fresh $\mathrm{LB}$ medium and shaken at $37^{\circ} \mathrm{C}$ until the $\mathrm{OD}_{600}=0.4$, and the IPTG was added (to a final concentration of $1 \mathrm{mM})$. Meanwhile, different concentrations of $\mathrm{Cu}^{2+}(30-1000 \mu \mathrm{M})$ and $\mathrm{Zn}^{2+}(10-100 \mu \mathrm{M})$ were also individually injected into the bacterial solution. Bacteria samples with no $\mathrm{Cu}^{2+}$ or $\mathrm{Zn}^{2+}$ added were seen as the control. After the bacteria were exposed to individual $\mathrm{Cu}^{2+}(30-1000 \mu \mathrm{M})$ or $\mathrm{Zn}^{2+}(10-100 \mu \mathrm{M})$ at induction, we selected the concentrations at which the hSOD1 activity was highest. Then three $\mathrm{Cu}^{2+}+\mathrm{Zn}^{2+}$ combinations $\left(750 \mu \mathrm{M} \mathrm{Cu}^{2+} / 15 \mu \mathrm{M} \mathrm{Zn}{ }^{2+} ; 1,500 \mu \mathrm{M} \mathrm{Cu}^{2+} / 15 \mu \mathrm{M}\right.$

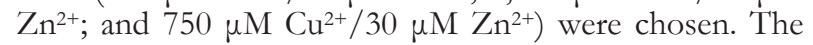
method of detecting hSOD1 activity was mentioned previously.

Effect of $\mathrm{Cu}^{2+}, \mathrm{Zn}^{2+}$, other metal ions and a denaturant on hSOD1 activity at the time of detection. To examine the effects of $\mathrm{Cu}^{2+}$ and $\mathrm{Zn}^{2+}$ on hSOD1 activity, various concentrations of $\mathrm{Cu}^{2+}(30,100,500,750$, $1000,2000,5000,6000 \mu \mathrm{M})$ and $\mathrm{Zn}^{2+}(10,20,30,100$, $500,1000,2000,5000,6000 \mu \mathrm{M})$ were added to the purified hSOD1. Meanwhile, a stock solution containing $\mathrm{CaCl}_{2}, \mathrm{MgCl}_{2}, \mathrm{MnCl}_{2}, \mathrm{FeCl}_{3}, \mathrm{CdCl}_{2}, \mathrm{NiSO}_{4}$ and $\mathrm{CoCl}_{2}$ was added to the purified hSOD1 to achieve $5 \mathrm{mM}$. Here, the purified hSOD1 was obtained from standard $\mathrm{LB}$ medium without supplementation $\mathrm{Cu}^{2+}$ and/or $\mathrm{Zn}^{2+}$. As a detergent, the effects of $1 \%, 5 \%, 10 \%$ SDS on the enzyme were also examined according to the aforementioned methods. The activity of the control enzyme with no metals or detergent was taken as $100 \%$. The results presented are the average of three independent experiments.

\section{RESULTS AND DISCUSSION}

\section{Expression and purification of recombinant protein}

The 465-bp DNA fragment of hSOD1 encoding the mature protein was cloned from the Bxpc3 cell line cDNA. DNA sequencing confirmed hSOD1 was correctly fused to the N-terminal His-tag, and it also revealed the cloned hSOD1 gene was the same as the published hSOD1 (GenBank accession number CR541742.1). In general, the exogenous recombinant plasmid that was expressed in E. coli BL21 easily formed inclusion bodies at $37^{\circ} \mathrm{C}$. Usually, lower temperatures were selected to induce the expression of infusion protein (Vasina \& Baneyx, 1997; Swalley et al., 2006; Huo et al., 2010). hSOD1 was largely expressed as an insoluble form when the expression of pET-28a (+)-hSOD1 was induced at $37^{\circ} \mathrm{C}$ with $1 \mathrm{mM}$ IPTG (Fig. 1A). The 

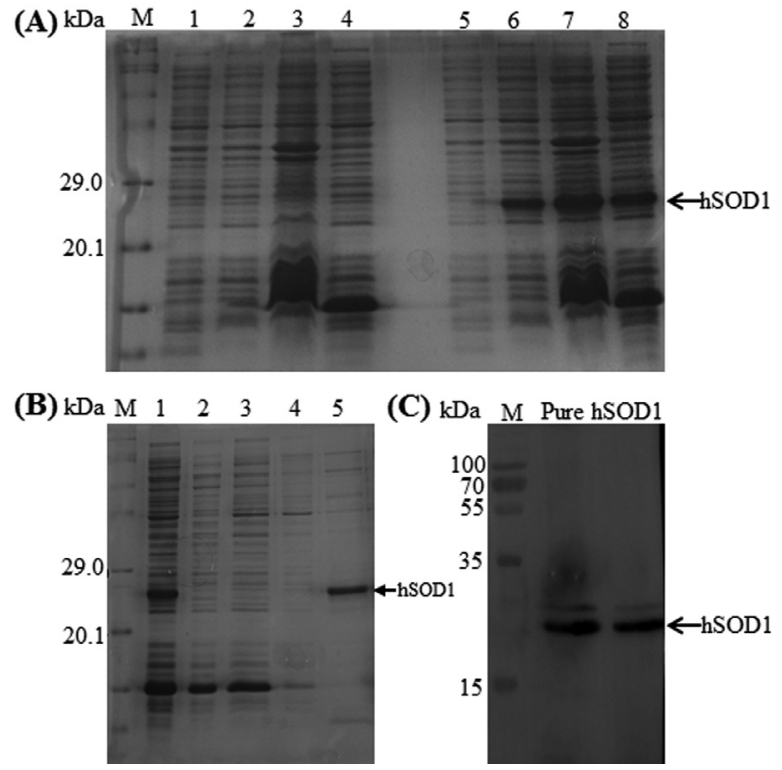

Figure 1. SDS-PAGE stained with Commassie blue and Western blotting analysis of recombinant hSOD1.

(A) Lane 1, 2: the total proteins of BL21 (DE3) harboring empty plasmid induced with $1 \mathrm{mM}$ IPTG at 0 and $5 \mathrm{~h}$; lane 3, 4: sediments and supernatants of BL21 (DE3) harboring empty plasmid with $1 \mathrm{mM}$ IPTG at $5 \mathrm{~h}$. lane 5, 6: the total proteins of BL21 (DE3) harboring the pET-28a (+)-hSOD1 induced with $1 \mathrm{mM}$ IPTG at 0 and $5 \mathrm{~h}$ lane 7, 8: sediments and supernatants of BL21 (DE3) harboring the pET-28a (+)-hSOD1 at 5 h. (B) lane 1: crude cell lysate of hSOD1; lane 2: surplus crude cell lysate of hSOD1 after incubating with $\mathrm{Ni}$-charged resin; lane 3: the flowing solution that $\mathrm{Ni}$-charged resin was washed using solution I (50 mM Tris, pH8.0, $300 \mathrm{mM} \mathrm{NaCl}, 50 \mathrm{mM}$ imidazole); lane 4: the flowing solution that $\mathrm{Ni}$-charged resin was washed using solution II $(50 \mathrm{mM}$ Tris, pH8.0, $300 \mathrm{mM} \mathrm{NaCl}, 100 \mathrm{mM}$ imidazole); lane 5: purified hSOD1 by dialysis. (C) Western blotting analyses of pure hSOD1. M: PageRuler Plus Prestained Protein Ladder.

theoretical molecular mass of hSOD1 is $15.9 \mathrm{kDa}$ (Ahl et al., 2004). The apparent molecular mass of hSOD1 expressed in $E$. coli was $20.1 \mathrm{kDa}$ as determined with SDS-PAGE, and the native enzyme had a size of 32 $\mathrm{kDa}$ ((Hartman et al., 1986). In the current study, a fiveHis-tag with a linker sequence was fused into the N-end hSOD1, so the apparent molecular weight of the recombinant hSOD1 is higher than $20.1 \mathrm{kDa}$, at 25-26 kDa (Fig. 1). It is unknown what caused the higher apparent molecular weight on SDS-PAGE. The SDS-PAGE method itself could be the reason of the higher appar- ent molecular weight observed on recombinant hSOD1 or due to some unknown posttranslational modifications.

The recombinant hSOD1 represented approximately $74 \%$ of the total bacterial protein, as was determined with densitometric scanning (Fig. 1A, lane 6). Protein expressions in the soluble and insoluble fractions were compared. Soluble and insoluble hSOD1 accounted for approximately $47 \%$ and $48 \%$ of the soluble and insoluble proteins, respectively (Fig. 1A, lanes 7, 8). Then, the soluble hSOD1 was purified to $90 \%$ with high affinity Ni-charged resin (Fig. 1B, lane 5). Further, we used western blotting to verify the purification results. In the Fig. 1C pure hSOD1 displays a major band identified using the anti His-tag antibody, and an extra minor band might represent aggregated hSOD1 or other proteins recognized by the antibody non-specifically. The amount of pure protein product was approximately $0.59 \mathrm{mg}$ per $100 \mathrm{~mL}$ E. coli culture, estimated using the Bradford method with BSA as the standard (see Table 1).

\section{Influence of $\mathrm{Cu}^{2+}$ and $\mathrm{Zn}^{2+}$ on hSOD1 activity at induction}

The correct coordination of $\mathrm{Cu}^{2+}$ and $\mathrm{Zn}^{2+}$ can ensure the structural integrity of hSOD1 Nordlund et al., 2009; Li et al., 2010). Under normal conditions, correctly folded SOD1 catalyzes the degradation of superoxide radicals (Shaw \& Valentine, 2007); however, the lack of $\mathrm{Cu}^{2+}$ and $\mathrm{Zn}^{2+}$ seriously affects the folding of the protein, leading to the loss of protein activity (Wittung-Stafshede, 2004; Rumfeldt et al., 2009). Given this phenomenon, various concentrations of $\mathrm{Cu}^{2+}, \mathrm{Zn}^{2+}$ and $\mathrm{Cu}^{2+}$ plus $\mathrm{Zn}^{2+}$ were added to the medium to see whether this altered the specific hSOD1 activity in crude bacterial lysates at induction. Our results showed that supplementation of $\mathrm{Cu}^{2+}$ and $\mathrm{Zn}^{2+}$ increased the specific activity of hSOD1. The highest enzymatic activity was observed when the individual $\mathrm{Cu}^{2+}$ and $\mathrm{Zn}^{2+}$ concentrations were $750 \mu \mathrm{M}$ and $15 \mu \mathrm{M}$ (Fig. 2), respectively, and the SOD1 activity declined when the concentrations of $\mathrm{Cu}^{2+}$ and $\mathrm{Zn}^{2+}$ continued to increase which indicated that excess $\mathrm{Cu}^{2+}$ and $\mathrm{Zn}^{2+}$ may be toxic to the cells at induction (Fig. 2). Furthermore, from Fig. 3, the yield of SOD1 did not significantly increase compared to the control.

The highest activity of hSOD1 produced with $750 \mu \mathrm{M}$ $\mathrm{Cu}^{2+}$ added was 7.7-fold greater than that of the control. This is consistent with a previous observation that supplementation of $\mathrm{Cu}^{2+}$ increases the specific activity of hSOD1 in E. coli (Hartman et al., 1986) and sf21 cells (Fujii et al., 1995). Our data showed that $\mathrm{Cu}^{2+}$ had no obvious effects on improving the solubility (data not shown) or enhancing the yield of SOD1 (Fig. 3A), but

Table 1. Purification of recombinant hSOD1 from a $100 \mathrm{~mL} E$. coli culture

\begin{tabular}{|c|c|c|c|c|c|}
\hline Proteins & $\begin{array}{l}\text { Total protein } \\
(\mathrm{mg})\end{array}$ & $\begin{array}{l}\text { Specific activity } \\
\text { (unit/mg) }\end{array}$ & $\begin{array}{l}\text { Total activity } \\
\text { (unit) }\end{array}$ & $\begin{array}{l}\text { Yield } \\
(\%)\end{array}$ & $\begin{array}{l}\text { Purification } \\
\text { (-fold) }\end{array}$ \\
\hline Cell lysate (all proteins of E. coli contained EP) & 6.0 & 29.0 & 174.0 & & \\
\hline $\begin{array}{l}\text { Cell lysate with expression of hSOD1b (all proteins of } E \text {. } \\
\text { coli contained RP) }\end{array}$ & 7.9 & 154.3 & 1219 & & \\
\hline hSOD1 in cell lysatec & 7.9 & 125.3 & 989.9 & 100.0 & 1.0 \\
\hline Purified hSOD1d & 0.59 & 1365.3 & 805.5 & 81.4 & 10.9 \\
\hline
\end{tabular}

a,b4 $\mathrm{mL}$ of supernatant were obtained through ultrasonication after $100 \mathrm{~mL}$. coli culture were collected. cthe enzyme specific activity of hSOD1 in cell lysate was calculated by subtracting the enzyme specific activity of cell lysate with empty vector from that of cell lysate with hSOD1 expression. $\mathrm{d} 3 \mathrm{~mL}$ of purified hSOD1 were obtained through nickel column chromatography from $4 \mathrm{~mL}$ of supernatant. EP: empty plasmid pET-28a (+). RP: recombinant plasmid containing the hSOD1 gene. 
(A)

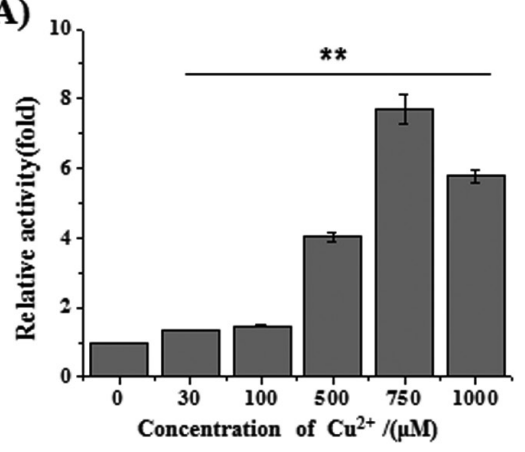

(B)

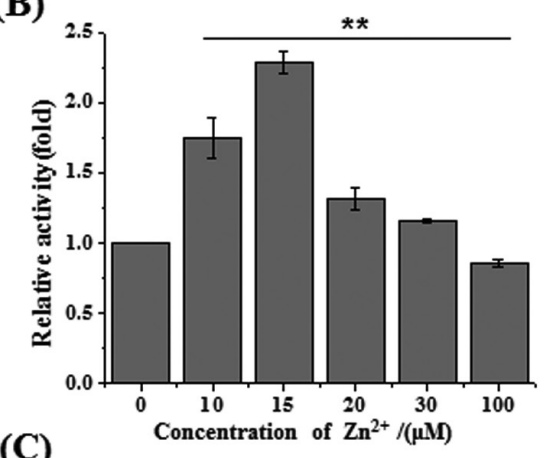

(C)

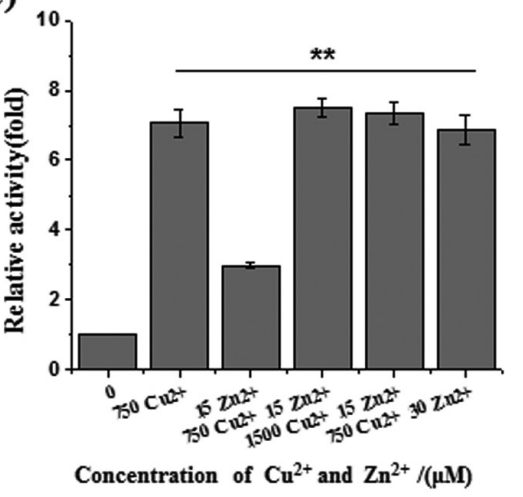

Figure 2. Activity of hSOD1 isolated from E. coli that was exposed to different concentrations of $\mathrm{Cu}^{2+}(\mathrm{A}), \mathrm{Zn}^{2+}(\mathrm{B}), \mathrm{Cu}^{2+}$ and $\mathrm{Zn}^{2+}(\mathrm{C})$.

$\mathrm{X}$-axis represents the different concentrations of ions. Y-axis represents the fold of specific activity. The control was set as 1. Data represent mean \pm S.D. for three independent experiments. ${ }^{*}$ indicates $P<0.01$.

it made a major contribution to the recovery of SOD1 activity (Fig. 2A).

$\mathrm{Li}$ and coworkers demonstrated that stoichiometric zinc played an important role in the oxidative refolding of bovine SOD1 by accelerating the oxidative refolding, suppressing aggregation during refolding and helping the protein to form a compact conformation with high protease resistance activity ( $\mathrm{Li}$ et al., 2010). We expected an increase in the soluble expression levels of SOD1 in E. coli upon supplementation with $\mathrm{Cu}^{2+}$ and $\mathrm{Zn}^{2+}$; however, no significant improvement in hSOD1 solubility was found by inducing at $37{ }^{\circ} \mathrm{C}$ compared with samples without supplementation $\mathrm{Cu}^{2+}$ and $\mathrm{Zn}^{2+}$ (data not shown). Meanwhile, a 2.3-fold increase in the specific activity of hSOD1 with $15 \mu \mathrm{M} \mathrm{Zn}^{2+}$ supplementation was observed. Fujii et al. reported that supplementation with $\mathrm{Zn}^{2+}$ alone did not enhance the SOD activity (Fujii et al., 1995), whereas our data showed that $\mathrm{Zn}^{2+}$ slightly increased SOD activity. Wu and coworkers noted that
(A) $\mathrm{Cu}^{2+} / \mu \mathrm{M}$

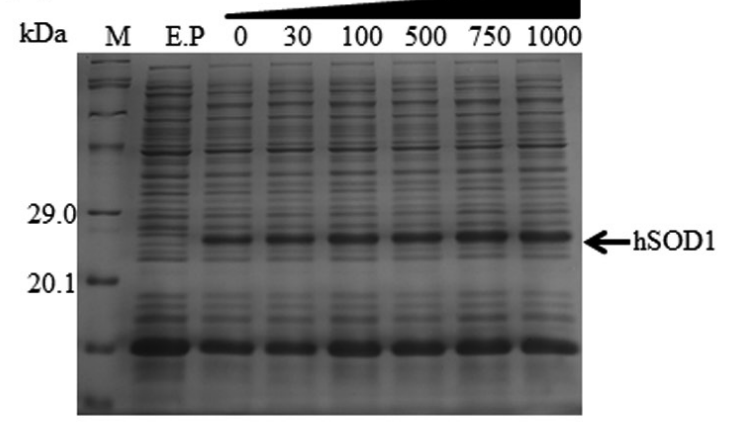

(B) $\mathrm{Zn}^{2+} / \mu \mathrm{M}$
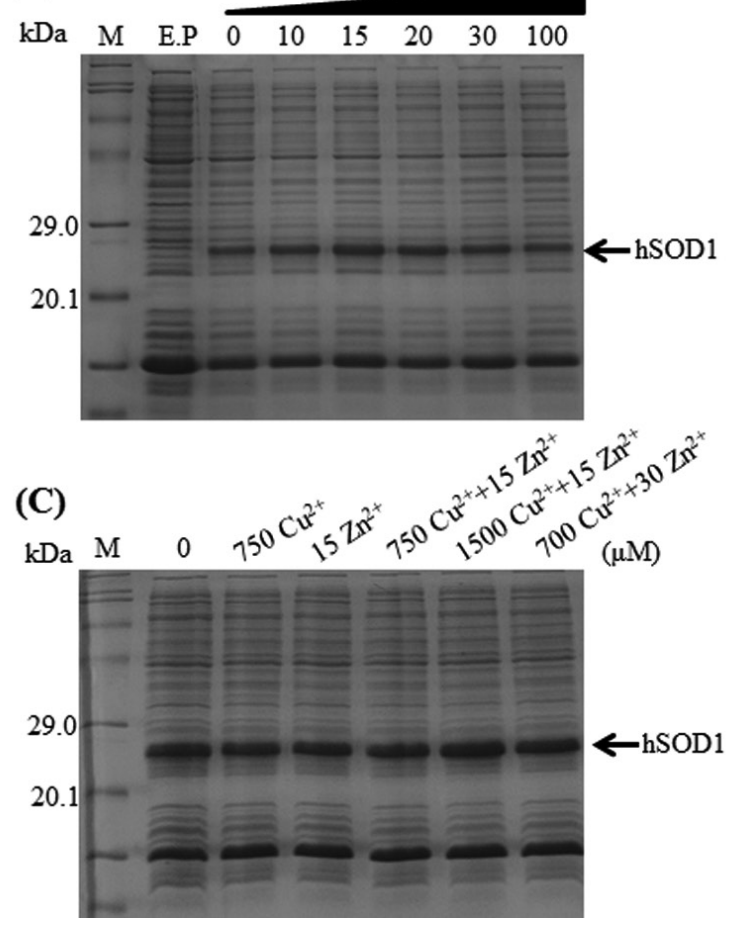

Figure 3. SDS-PAGE analyses of hSOD1 isolated from $E$. coli that was exposed to different concentrations of $\mathrm{Cu}^{2+}(A), \mathrm{Zn}^{2+}(\mathrm{B})$, $\mathrm{Cu}^{2+}$ and $\mathrm{Zn}^{2+}(\mathbf{C})$.

M: protein molecular weight marker; E.P: empty plasmid pET-28a $(+)$.

SOD1 activity was decreased by about 50\% in zinc-limited cells (Wu et al., 2009). Li et al. indicated that copper played a dominant role in SOD1 activity and zinc only made a small contribution to SOD1 activity (Li et al., 2010).

The specific activity of hSOD1 upon supplementation with $750 \mu \mathrm{M} \mathrm{Cu}{ }^{2+} / 15 \mu \mathrm{M} \mathrm{Zn}^{2+}$ (Fig. 2C) was 7.5-fold greater than that of the control, which was approximately equal to 7.7-fold enhancement with supplementation of $750 \mu \mathrm{M} \mathrm{Cu}^{2+}$ alone. This implied that, when the $\mathrm{Cu}^{2+}$-binding sites were fully saturated, it was possible that the metallation of $\mathrm{Cu}^{2+}$ site facilitated the metallation of $\mathrm{Zn}^{2+}$ sites or the $\mathrm{Zn}^{2+}$ could be replaced by $\mathrm{Cu}^{2+}$ with full function. Crow and coworkers reported that zinc was more likely to disassociate than copper, because SOD has an approximately a 7000-fold lower affinity for zinc than it does for copper (Crow et al., 1997).

The completely metal-free apo-hSOD1 has no specific activity (Hartman et al., 1986). Hartman and coworkers 
Table 2. Effects of metal ions and denaturant on the purified hSOD1

\begin{tabular}{llc}
\hline Metals/denaturant & Concentration & Relative activity (-fold) \\
\hline Control & 0 & $1.0 \pm 0.00$ \\
\hdashline $\mathrm{CaCl}_{2}$ & $5 \mathrm{mM}$ & $1.9 \pm 0.20$ \\
\hline $\mathrm{MgCl}_{2}$ & $5 \mathrm{mM}$ & $1.4 \pm 0.31$ \\
\hdashline $\mathrm{MnCl}_{2}$ & $5 \mathrm{mM}$ & $16.9 \pm 1.62$ \\
\hline $\mathrm{FeCl}_{3}$ & $5 \mathrm{mM}$ & $5.5 \pm 0.25$ \\
\hdashline $\mathrm{CdCl}_{2}$ & $5 \mathrm{mM}$ & $3.9 \pm 0.38$ \\
\hline $\mathrm{NiSO}_{4}$ & $5 \mathrm{mM}$ & $3.4 \pm 0.35$ \\
\hline $\mathrm{CoCl}_{2}$ & $5 \mathrm{mM}$ & $6.7 \pm 0.25$ \\
\hline $\mathrm{SDS}$ & $1,5,10 \%$ & $0.0 \pm 0.00$ \\
\hline
\end{tabular}

Control activity (1.0) was determined when none of the metal ions were added. Data represent mean \pm S.D. for three independent experiments.

suggested that the intracellular concentration of $\mathrm{Cu}^{2+}$ in $E$. coli is insufficient to saturate human CuZnSOD, especially at high expression levels (Hartman et al., 1986). Our results showed that, in LB medium, the addition of $750 \mu \mathrm{M}$ of $\mathrm{Cu}^{2+}$ to the medium apparently raised the intracellular $\mathrm{Cu}^{2+}$ concentration to levels that are sufficient to saturate the active sites for the overproduced hSOD1. In contrast, adequate $\mathrm{Zn}^{2+}$ was incorporated into hSOD1 when $15 \mu \mathrm{M}$ of $\mathrm{Zn}^{2+}$ was present in the medium.

\section{Effects of $\mathrm{Cu}^{2+}, \mathrm{Zn}^{2+}$, the other metal ions and a denaturant on hSOD1 activity at the time of detection}

To study the effects of $\mathrm{Cu}^{2+}$ and $\mathrm{Zn}^{2+}$ on hSOD1 enzymatic activity, we added various concentrations of $\mathrm{Cu}^{2+}$ and $\mathrm{Zn}^{2+}$ to the purified hSOD1. The results showed that specific hSOD1 activity significantly increased at concentration of $\mathrm{Cu}^{2+}$ ranging from 30 to $6000 \mu \mathrm{M}$ (Fig. 4A). The specific hSOD1 activity only slightly increased with 0-2000 $\mu \mathrm{M} \mathrm{Zn}^{2+}$, but it significantly increased at $\mathrm{Zn}^{2+}$ concentrations of 5000 and $6000 \mu \mathrm{M}$ (Fig. 4B). This indicated that $\mathrm{Cu}^{2+}$ and $\mathrm{Zn}^{2+}$ also enhanced the enzyme activity at the time of detection.

The effects of the other metal ions and a denaturant on the purified recombinant hSOD1 were studied and are shown in Table 2. hSOD1 exhibited high activity at $5000 \mu \mathrm{M} \mathrm{Cu}^{2+}$ or $\mathrm{Zn}^{2+}$ (Fig. 4). Then, we selected $5 \mathrm{mM}$ of metal ions $\left(\mathrm{CaCl}_{2}, \mathrm{MgCl}_{2}, \mathrm{MnCl}_{2}, \mathrm{FeCl}_{3}, \mathrm{CdCl}_{2}, \mathrm{NiSO}_{4}\right.$ and $\mathrm{CoCl}_{2}$ ), and individually added them to the purified hSOD1. Compared to the control without metals, the activity of hSOD1 was enhanced to varying degrees. The influences of $\mathrm{Co}^{2+}$ and $\mathrm{Mn}^{2+}$ on the activity of hSOD1 were very significant, in that the activity increased by 6.7- and 16.9-fold compared to the control. hSOD1 exhibited little effect upon the addition of other metal ions $\left(\mathrm{Ca}^{2+}, \mathrm{Mg}^{2+}, \mathrm{Fe}^{3+}, \mathrm{Cd}^{2+}\right.$, and $\left.\mathrm{Ni}^{2+}\right)$, whose influence ranged from 1.9- to 5.5-fold. From these results, we determined that all of the divalent metal ions $\left(\mathrm{M}^{2+}\right)$ have the potential to replace $\mathrm{Zn}^{2+}$ and $\mathrm{Cu}^{2+}$. Furthermore, the activity of hSOD1 was totally inhibited by SDS.

Substitutions of the native $\mathrm{Cu}$ and $\mathrm{Zn}$ ions by nonnative metal ions cause minimal structural changes, and result in high enzymatic activity for those derivatives when $\mathrm{Cu}$ remains in the $\mathrm{Cu}$ site. Studies of the derivatives in which $\mathrm{Zn}^{2+}$ was replaced by another divalent metal ion, $\mathrm{M}^{2+}$ (i.e., $\mathrm{Cu}_{2} \mathrm{M}_{2} \mathrm{SOD} 1$ with $\mathrm{M}=\mathrm{Co}, \mathrm{Ni}, \mathrm{Cd}$, $\mathrm{Hg}, \mathrm{Cu}$ ) found the enzyme to be little changed structurally by the metal ion replacement and to retain full enzy-
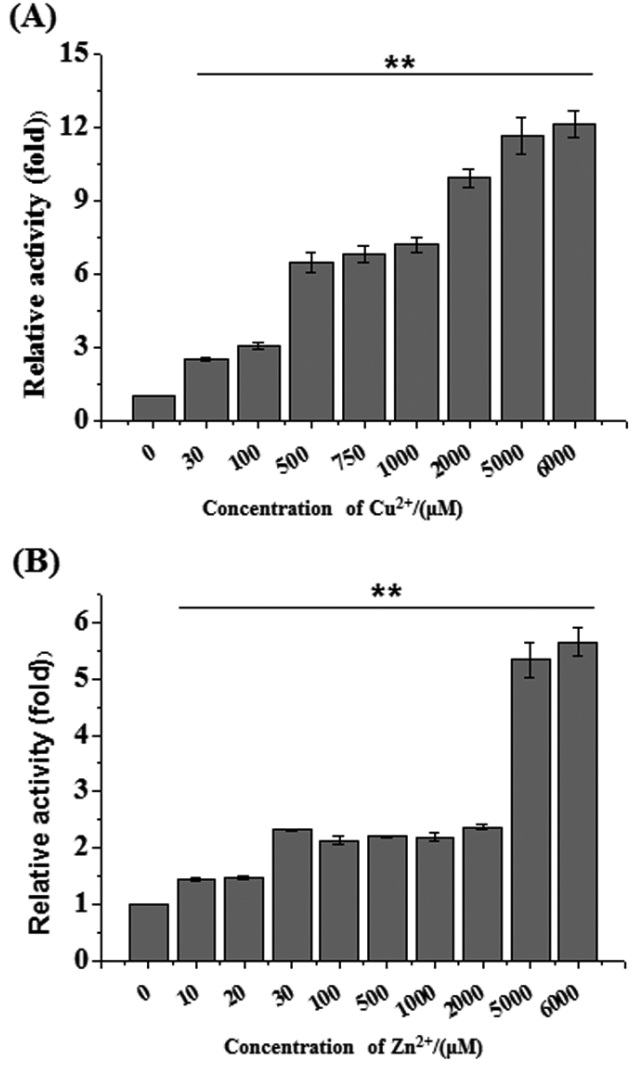

Figure 4. Effects of $\mathrm{Cu}^{2+}(\mathrm{A})$ and $\mathrm{Zn}^{2+}(\mathrm{B})$ on purified hSOD1 activity.

$\mathrm{X}$-axis represents the different concentrations of ions. Y-axis represents the fold of specific activity. The control was set as 1 . Data represent mean \pm S.D. for three independent experiments. ${ }^{*}$ indicates $P<0.01$.

matic activity. Studies of the derivatives in which $\mathrm{Cu}$ was replaced by another metal ion (i.e., $\mathrm{M}_{2} \mathrm{Zn}_{2} \mathrm{SOD} 1$ with $\mathrm{M}=\mathrm{Co}, \mathrm{Ni}, \mathrm{Ag}, \mathrm{Cd}, \mathrm{Zn}$ ) also suggested that non-native metal ion substitutions causes little if any rearrangement of the ligand geometries in the metal binding region of the protein (Ming \& Valentine, 2014).

$\mathrm{Mn}^{2+}$ is essential for the activation of SOD2 as it acts as a cofactor that coordinates with each of the enzyme's four subunits. Ghneim and coworkers reported there were statistically significant increases in SOD2 activities in senescent fibroblasts incubated with all of the $\mathrm{Mn}^{2+}$ supplemented media (Ghneim, 2016). Our results suggested that supplementation of $\mathrm{Mn}^{2+}$ could also significantly increase the specific activity of hSOD1. One possibility is that SOD1 and SOD2 have a close evolutionary relationship (Haddad \& Yuan, 2005). These studies provide some reference points for improving the catalytic efficiency of the enzyme.

\section{CONCLUSIONS}

In this research, we have cloned and expressed a homo $\mathrm{Cu} / \mathrm{Zn} \mathrm{SOD}, \mathrm{hSOD} 1$ in E. coli BL21 (DE3). The purified recombinant hSOD1 protein was capable of inhibiting the formation of formazan dye suggesting that the hSOD1 gene encodes a functional superoxide dismutase. Considering that metal cofactors are essential to the structure and activity of hSOD1, hSOD1 activity was measured upon the addition of $\mathrm{Cu}^{2+}$ and $\mathrm{Zn}^{2+}$ at induction compared to no addition. The results implied that 
$\mathrm{Cu}^{2+}$ and $\mathrm{Zn}^{2+}$ do not enhance SOD1 expression and solubility; however, they can improve the catalytic activity at induction. This adequately showed that the recombinant hSOD1 was well folded in the presence of $\mathrm{Cu}^{2+}$ and $\mathrm{Zn}^{2+}$, and would be suitable for further functional study. Meanwhile, $\mathrm{Cu}^{2+}$ and $\mathrm{Zn}^{2+}$ also enhanced the enzyme activity at the time of detection. Furthermore, most other bivalent cations had the potential to replace $\mathrm{Zn}^{2+}$ and $\mathrm{Cu}^{2+}$, and also improved enzyme activity at the time of detection.

\section{Acknowledgements}

This work was supported by grants from the National Natural Science Foundation of China (No. 31301919, 31271272, 31402328), Major Program of Increase or Decrease in the Central Government (No. 2060302), Natural Science Foundation of Anhui Province No. 1508085MH203), Natural Science Foundation of the Higher Education Institutions of Jiangsu Province (No. 13KJB18005), and Start-Up Research Funding of Jiangsu University (No. 1281330018).

\section{REFERENCES}

Ahl IM, Lindberg MJ, Tibell LA (2004) Coexpression of yeast copper chaperone (yCCS) and CuZn-superoxide dismutases in Eschericbia coli yields protein with high copper contents. Protein Expr Purif 37: 311-319. doi: 10.1016/i.pep.2004.06.006

Banci L, Barbieri L, Bertini I, Cantini F, Luchinat E (2011) In-cell NMR in E. coli to monitor maturation steps of hSOD1. PLoS One 6: e23561. doi: 10.1371/journal.pone.0023561

Crow JP, Sampson JB, Zhuang Y, Thompson JA, Beckman JS (1997) Decreased zinc affinity of amyotrophic lateral sclerosis-associated superoxide dismutase mutants leads to enhanced catalysis of tyrosine nitration by peroxynitrite. J Neurochem 69: 1936-1944

Eiamphungporn W, Yainoy S, Prachayasittikul V (2016) Enhancement of solubility and specific activity of a $\mathrm{Cu} / \mathrm{Zn}$ superoxide dismutase by Co-expression with a copper chaperone in Escherichia coli. Iran J Biotechnol 14: 243-249. doi: 10.15171/ijb.1465

Fujii J, Myint T, Seo HG, Kayanoki Y, Ikeda Y, Taniguchi N (1995) Characterization of wild-type and amyotrophic lateral sclerosis-related mutant CuZn-superoxide dismutases overproduced in baculovirus-infected insect cells. J Neurochem 64: 1456-1461

Geraghty P, Baumlin N, Salathe MA, Foronjy RF, D'Armiento JM (2016) Glutathione Peroxidase-1 suppresses the unfolded protein response upon cigarette smoke exposure. Mediators Inflamm 2016: 9461289. doi: 10.1155/2016/9461289

Ghneim HK (2016) The kinetics of the effect of manganese supplementation on SOD2 activity in senescent human fibroblasts. Eur Rev Med Pharmacol Sci 20: 1866-1880

Girotto S, Cendron L, Bisaglia M, Tessari I, Mammi S, Zanotti G, Bubacco L (2014) DJ-1 is a copper chaperone acting on SOD1 activation. J Biol Chem 289: 10887-10899. doi: 10.1074/jbc.M113.535112

Haddad NI, Yuan Q (2005) Purification and some properties of CuZn superoxide dismutase from Radix lethospermi seed kind of Chinese traditional medicine. J Chromatogr B Analyt Technol Biomed Life Sci 818: 123-131. doi: 10.1016/j.jchromb.2004.12.010

Hartman JR, Geller T, Yavin Z, Bartfeld D, Kanner D, Aviv H, Gorecki M (1986) High-level expression of enzymatically active human $\mathrm{Cu} / \mathrm{Zn}$ superoxide dismutase in Escherichia coli. Proc Natl Acad Sci U S A 83: 7142-7146

Hayward LJ, Rodriguez JA, Kim JW, Tiwari A, Goto JJ, Cabelli DE, Valentine JS, Brown RH Jr (2002) Decreased metallation and activity in subsets of mutant superoxide dismutases associated with familial amyotrophic lateral sclerosis. J Biol Chem 277: 15923-15931. doi: 10.1074/jbc.M112087200

Hole PS, Darley RL, Tonks A (2011) Do reactive oxygen species play a role in myeloid leukemias? Blood 117: 5816-5826. doi: 10.1182/ blood-2011-01-326025

Huo J, Shi H, Yao Q, Chen H, Wang L, Chen K (2010) Cloning and purification of recombinant silkworm dihydrolipoamide dehydrogenase expressed in Escherichia coli. Protein Expr Purif 72: 95-100. doi: 10.1016/j.pep.2010.01.014
Johnson P (2002) Antioxidant enzyme expression in health and disease: effects of exercise and hypertension. Comp Biochem Physiol C Toxicol Pharmacol 133: 493-505

Kilic N, Taslipinar YM, Guney Y, Tekin E, Onuk E (2014) An investigation into the serum thioredoxin superoxide dismutase malondialdehyde and advanced oxidation protein products in patients with breast cancer. Ann Surg Oncol 21: 4139-4143. doi: 10.1245/s10434014-3859-3

Leitch JM, Jensen LT, Bouldin SD, Outten CE, Hart PJ, Culotta VC (2009) Activation of CuZn-superoxide dismutase in the absence of oxygen and the copper chaperone CCS. J Biol Chem 284: 21863 21871. doi: 10.1074/jbc.M109.000489

Li HT, Jiao M, Chen J, Liang Y (2010) Roles of zinc and copper in modulating the oxidative refolding of bovine copper zinc superoxide dismutase. Acta Biochim Biophys Sin (Shanghai) 42: 183-194

Lin C, Zeng H, Lu J, Xie Z, Sun W, Luo C, Ding J, Yuan S, Geng M, Huang M (2015) Acetylation at lysine 71 inactivates superoxide dismutase 1 and sensitizes cancer cells to genotoxic agents. Oncotarget 6: 20578-20591. doi: 10.18632/oncotarget.3987

Ming LJ, Valentine JS (2014) Insights into SOD1-linked amyotrophic lateral sclerosis from NMR studies of $\mathrm{Ni}(2+)$ - and other metal-ionsubstituted wild-type copper-zinc superoxide dismutases. J Biol Inorg Chem 19: 647-657. doi: 10.1007/s00775-014-1126-5

Nordlund A, Leinartaite L, Saraboji K, Aisenbrey C, Grobner G, Zetterstrom P, Danielsson J, Logan DT, Oliveberg M (2009) Functional features cause misfolding of the ALS-provoking enzyme SOD1. Proc Natl Acad Sci US A 106: 9667-9672. doi: 10.1073/ pnas.0812046106

Park DH, Yoon S-YH Nam HG, Park JM (2002) Expression of functional human-cytosolic $\mathrm{Cu} / \mathrm{Zn}$ superoxide dismutase in transgenic tobacco. Biotechnology Letters 24: 681-686

Rumfeldt JA, Lepock JR, Meiering EM (2009) Unfolding and folding kinetics of amyotrophic lateral sclerosis-associated mutant $\mathrm{CuZn}$ superoxide dismutases. J Mol Biol 385: 278-298. doi: 10.1016/j. jmb.2008.10.003

Sangwan S, Zhao A, Adams KL, Jayson CK, Sawaya MR, Guenther EL, Pan AC, Ngo J, Moore DM, Soriaga AB (2017) Atomic structure of a toxic oligomeric segment of SOD1 linked to amyotrophic lateral sclerosis (ALS). Proc Natl Acad Sci: 201705091

Shaw BF, Valentine JS (2007) How do ALS-associated mutations in superoxide dismutase 1 promote aggregation of the protein? Trends Biochem Sci 32: 78-85. doi: 10.1016/j.tibs.2006.12.005

Shih LY, Liou TH, Chao JC, Kau HN, Wu YJ, Shieh MJ, Yeh CY, Han BC (2006) Leptin superoxide dismutase and weight loss: initial leptin predicts weight loss. Obesity (Silver Spring) 14: 2184-2192. doi: 10.1038 /oby. 2006.256

Swalley SE, Fulghum JR, Chambers SP (2006) Screening factors effecting a response in soluble protein expression: formalized approach using design of experiments. Anal Biochem 351: 122-127. doi: 10.1016/j.ab.2005.11.046

Vasina JA, Baneyx F (1997) Expression of aggregation-prone recombinant proteins at low temperatures: a comparative study of the Escherichia coli cspA and tac promoter systems. Protein Expr Purif 9: 211-218. doi: 10.1006/prep.1996.0678

Vats P, Sagar N, Singh TP, Banerjee M (2015) Association of superoxide dismutases (SOD1 and SOD2) and glutathione peroxidase 1 (GPx1) gene polymorphisms with type 2 diabetes mellitus. Free Radic Res 49: 17-24. doi: 10.3109/10715762.2014.971782

Wittung-Stafshede P (2004) Role of cofactors in folding of the bluecopper protein azurin. Inorg Chem 43: 7926-7933. doi: 10.1021/ ic049398g

Wu CY, Steffen J, Eide DJ (2009) Cytosolic superoxide dismutase (SOD1) is critical for tolerating the oxidative stress of zinc deficiency in yeast. PLoS One 4: e7061. doi: 10.1371/journal.pone.0007061

Yoo HY, Kim SS, Rho HM (1999) Overexpression and simple purification of human superoxide dismutase (SOD1) in yeast and its resistance to oxidative stress. I Biotechnol 68: 29-35

Zhang K, Zhang Y, Zi J, Xue X, Wan Y (2017) Production of human CuZn SOD with higher activity and lower toxicity in E. coli via mutation of free cysteine residues. Biomed Res Int 2017: 4817376. doi: 10.1155/2017/4817376

Zhou Y, Yuan S, Liu Q, Yan D, Wang Y, Gao L, Han J, Shi H (2017) Synchronized purification and immobilization of his-tagged betaglucosidase via Fe3O4/PMG core/shell magnetic nanoparticles. Sci Rep 7: 41741. doi: 10.1038/srep41741 